\title{
The environmental education and the risk literacy: an approach to a healthy and sustainable society
}

\author{
D. M. B. Bonotto
}

Centro de Educação e Ciências Humanas, Universidade Federal de São Carlos, São Carlos, Brasil.

\begin{abstract}
The discussions relative to environmental problems have increased around the world in the last decades since it is possible to identify their interferences in the human life as well in all forms of life in the planet. Actually these problems have been associated with the concept of environmental risks, characterizing our contemporaneous risks's society. The educational instituition was requested to contribute with the reflections and actions about the environmental questions, as demonstrate the several international meetings already organized, which indicated objectives and general guidances for the Environmental Education. In this paper, I intend to contribute to the environmental risks's debate, discussing the role of the educative work in order to promote a healthy and sustainable society.
\end{abstract}

\section{Introduction}

The preoccupation with the environmental questions have been more accentuated in the last decades, since it has been verified a gradual increase of the problems related to the environmental degradation, which progressively reach more gravity and extension.

Toynbee [1] considers the environmental question as the fundamental contradiction established among the models of development adopted by the man, starting mainly in 18th century, and the sustentation of this development by the nature. According to this author, after the industrial revolution, the velocity of production of wastes from the society, the crescent urbanization, and the polluting power of the industrial activities greatly exceeded the regenerative 
capacity of the ecosystems to cycle the renewal of the natural resources, causing, as a consequence, a drastic reduction of the non-renewable natural resources.

Such problems conducted the humanity to worry about these subjects under a revision process, not only taking into account the economic production style as pointed out by Gonçalves [2], but fundamentally considering the way of life. According to this author, the ecological movements started worldwide in the 1960's decade together with several other social movements, being the environmental movements those that more extensively inquired the present conditions of life.

Joining to these reflections, the report of the Brundtland Commission (Our Common Future) introduced the idea of "sustainable development" as a means of reconciling economic and technological development with the respect for the environment. As Glasbergen [3] says, "'Sustainable development' expresses the aspirations of societies to iniciate a process of social change and to start by improving the environment. The concept indicates a path for comprehensive development, and it is thus a source of inspiration". But in the same time it means an aspiration, Neace [4] emphasizes that "Although widely hailed conceptually, sustainable development is highly controversial with regard to policies and practices of bringing ecology and economy into harmony with each other".

There are many discourses about sustainable development, each one serving to different purposes. However, in the context of this paper, the idea of sustainability means a transformation that involves a revolution in institutions, systems, lifestyles and values of our western culture, thing that only a few people is aware or wishing for it.

Another discussion that came actually to the environmental reflection is about the concern of risks. The enhancement of the impact of the natural hazards due to the human action (the progressive invasion of critical areas, global changes related to climatic modifications, and also negative consequences generated by technological innovations) allowed to modify the idea of danger to that of environmental risk. This includes a dimension of predictable and, consequently, the environmental problems are now associated with the concept of environmental risks, characterizing our contemporaneous risks's society. Thus, the efforts are in the direction of the assessment to avoid these risks, including the application of suitable experimental modelling and interpretative techniques.

There is a fundamental aspect that should not be forgotten, being necessary to be considered in this assessment. Increasing social disequilibria in the distribution of wealth has been detected by the social studies, and, by the same way that the understanding of sustainable development for many people can not take into account, we also have, in several situations, unequal distribution of environmental risks, what is needed to be considered in our analyses of trying to solve these problems, if the real desire is to find long-term solutions. The contribution from social sciences is fundamental for a deeper understanding of this problematic, as well for a more coherent and effective action.

Gonçalves [2], when discussing about the fact of the natural sciences and human sciences have been separated, i.e. without communication, considers that 
the environmental questions can not be only reduced to any of these two fields, since they are deeply related to the relationship between the society and the nature, implying on both "the social relations and the complex relations between the physical-chemical world and organic world". Thus, none specific area of knowledge is able to decide alone about this relationship, being necessary a contribution of all them for such objective, through a broad dialogic process that approximates a democratic process.

In this paper, I focus the educational area under such perspective, trying to find the contribution it may offer to the understanding and guidance of the environmental questions in the educational proposals.

\section{The environmental thematic and the educational process}

The preoccupations relative to the environmental thematic reached the educational field, which was claimed to give its contribution in order to revert or minimize the spectrum of disequilibria established in the planet. The "United Nations Conference on the Human Development" at Stockholm in 1972 was the first official observation concerning to the need of searching solutions to the problems of environmental degradation. As an aid to this search and as the first step for acting and controlling the environmental problems, it was recommended the development of an international program for environmental education, with the aim to educate the citizen for understanding the mechanisms that are responsible to sustain the life on Earth.

Several meetings occurred afterwards up to "The First Intergovernmental Conference on Environmental Education" organized by UNESCO (Tbilisi, Geórgia, 1977). This conference grouped more than 300 specialists from the entire world, being performed recommendations that became indispensable reference to all people interested on environmental education.

The importance of this conference is related to the fact that it was shown a critical vision involving the environmental problems, pointing out to their political, economic, social, and cultural aspects. Layrargues [5] suggested that it contributed to the rupture of the previous vision, which was linked to a reductionist ecological vision that had implied on an educational proposal strictly conservationist, simplistic and not contextual.

However, the environmental education has yet a strong tradition in the form of nature study or environmental science studies, seeing the individual behavioural change as its task. As Corcoran and Sievers [6] emphasized, in these cases the structural causes of environmental problems are rarely examined, and the environmental issues are presented as asocial or universal problems, not related to underlying social forces.

Fien, Robottom, Gough, and Spork [7], in the foreword of their book explained exactly the necessity of a broad approach: “(...) the root causes of environmental problems are located in the very nature of our current social, economic and political systems and in the world views, institutions and lifestyle choices that support them. This means that solving environmental problems 
requires a wider response than the training of skilled environmental managers or the training of teachers in ecology and the interpretation of nature. Environmental education involves much more than this. It has evolved as a field of professional practice to address the changes in personal values and social structures that are necessary to support ecologically sustainable and socially just ways of organising people-nature and people-environment relationships".

Considering these ideas, Fien and Trainer [8] emphasize that one of the tasks for environmental education is to help the people to understand that the transition to a sustainable society is necessary, and other is to believe that the alternative would yield a higher quality of life.

Breiting and Mogensen [9] also argue that there are two different approaches to environmental education. One they call "the action competence" and it is related to developing a critical, reflective and participatory approach by which the developing adult can cope with future environmental problems. The other is the behaviour modification approach, that aims at pupils behaviour patterns which we here and now believe will contribute to solving current environmental problems.

For Breiting and Mogensen [9], an "assessment of the objective of the first approach must be seen in connection with whether is has developed the pupils' will and ability to be involved in environmental issues in a democratic way, by forming their own criteria for decision making and choise of action. Action must in this sense be seen in a future perspective, where direction is not given beforehand". They also say that all environmental issues involve conflicting interests in the community, that appear at least at three levels:

- individual level: the conflict exists between incompatible needs and wishes, often expressed as personal dilemmas;

- social level: the conflicting interests exist between various groups and/or individuals;

- the structural level of society: the conflicting interests can be regarded as conflicts between political decisions and market forces or economical mechanisms.

So, for Breiting and Mogensen [9], if the enviromental education is to deal with the real enviromental issues it has to face all the three levels of conflicting interests.

Thinking in this direction, I agree that the task of the environmental education can not stay in the individual behaviour change because it involves a transformation in the world's conditions promoted for a critical and participant society by the democratic way. Then, only this process will be able to conduct to the sustainability by the guarantee of the negotiation's places.

Several authors have adopted an environmenal education approach under this view [5-11], so that it has been seen as the new generation of environmental education.

I also consider that to take into account this broad approach thinking mainly in the society's view, it does not mean to forget the individual aspect. In accordance with Fien [12], the education to the sustainability must be based upon 
the dynamic interdependence of personal and structural transformation; furthermore, it can not be based upon changing individual values or lifestyles or through structural changes only.

I can see these two aspects in a systemic perspective analogously to that situation often observed in a good healthy treatment: after the observation of the symptoms and the identification of the real illness, we follow the health care necessary to eliminate both, i.e. their causes and symptoms. However, the opposite is not valid, since only treating the symptoms do not signify cure.

From this broad and systemic approach, an interesting way of thinking about the projects on environmental education is to consider in their objectives the following aspects pointed out by Carvalho [13]:

- the knowledge (to deal with facts and concepts from the natural/social sciences, as well with the process of production of the knowledge itself);

- the values (ethics and aesthetics, for constructing new standards of relations with the natural environment);

- the political participation (for development of the citizenship and construction of a democratic society).

All these aspects will be considered on the next discussion on the possibilities of the educational work related to the risk literacy.

\section{Environmental education and the risk literacy}

Several authors say that the individuals often demonstrate unrealistic views and behaviours towards hazards and the risks that they pose. The perception of the risk is learned in our lives, then it is an important matter of the environmental education. As Riechard [14] says, "accurate perceptions of risk are necessary for the attainment of a risk-literate society", and the educational process has an important contribution to give. But Riechard [14] argues, based on other authors, that except in a few extreme causes, education and the general public have been outside the information and policy-making structures: public education has been considered a peripheral aspect of the risk policy process, secondary to more important measures such as warning systems, information management, resource management and hazard response procedures.

Layrargues [5], discussing about the economic and social aspects of the risks debate, emphasizes the pronounced gravity exhibited by the question when are taken into account the poorest populations living at risks'areas, since they are more affected by these situations. The author presents several studies realized in Brazil, in which different situations revealed the gravity:

- the poorest people accept to live at risk's areas and also have a passive attitude in relation to the situation, only waiting for the governmental action to the solution of the problem;

- despite these people to be more exposed to the environmental risks, they have less conditions for spatial mobility in order to escape of the situation of risk; they also have less informations to understand the situation of risk and to find the ways to solve it; 
- juridic processes defending the environment originate from people basically belonging to middle-class and higher, indicating none initiative of the other, even those more affected by the environmental risk.

Therefore, the contribution of the educational process is much more urgent and necessary when these cases are considered. It must assist on understanding the risk's situation, and also the immediate and more profound causes that have conditionated it. Such comprehension is fundamental for the individuals critically to act.

Thus, which is the contribution that the educative process can do? Despite the importance of the information's aspect, the education can not only take it into account, as frequently people think and say.

Firstly, because the simple information is not enough to cause changes. Under this point of view and based on the studies of Social Psychology, Mandel [15] details the fact that the knowledge of an environmental problem is not enough to promote changes in the individual behaviour. The author continues presenting several factors determinative of the behaviour: the characteristics of the problem (consequences of short or long-term, noticeable or non-noticeable impacts, etc.), the individual profile of the subject (his values, age, social class, etc.), and the cultural context where he is inserted. All these factors will act together, determining how much a person becomes affected by a problem, and actively decides to work for its solution.

Secondly, considering again the previous aspects concerning to the broader function of the environmental education, it is not convenient to regard risk literacy only as a question of individual behaviour change, but wider conquests must be desired. The environmental education should develop democratic forms of popular participation, allowing the society to learn how to fight collectively by their rights, as well to be responsible by a more equilibrated and healthy environment, surpassing the limitations of waiting and confidentially obey the decisions from specialists and governmental agencies.

Taking into account these arguments and remembering the three aspects proposed by Carvalho [13] on establishing the objectives of a project of environmental education, now are presented some suggestions relative to educational works with the thematic of environmental risks.

\subsection{Knowledge}

It was already said that are rare the informations arriving to the population, and, therefore, it should be desired an enlargement of the communication channels. However, it is necessary to reinforce that these informations are not restricted to technical features, also referring to informations concerning to other, like social, economical and political, so that different sectors and fields of knowledge should be engaged in this task, under which case, could occur a wide and convenient discussion process focusing these informations, inclusive regarding the interest conflicts.

It is also convenient to regard the arguments of Santos [16] that the analysis focusing the relationship between science, technology, and society, widely 
pointed out from the 80's, have been considered essential for the public to understand the influence of these sectors in their lives and to use this knowledge for making an individual and collective decision, without taking into account attitudes debilitated by an ingenuous optimism or a prejudicial hostility relative to these sectors.

\subsection{Values}

According to the informations expressed by Mandel [15], the values domain originates among the factors interfering in the process of perception and action related to the environmental risk, taking into account the individual profile of the subject (including his personal values), as well the cultural context (since the individual values are highly associated with the values of the associated social group).

The analysis of the environmental perception of people directly engaged in environmental problems can show such outline. Many of their discourses are apparently without meaning to the external observer, existing, on other hand, an occult meaning containing relevant aspects of the question directly related to the values domain. Silences and negation of the problem are accompanied by talks that often reveal "other values" (like the oportunity for a job) that are considered more important than the solution of the environmental problem, which becomes non-relevant. These aspects were observed by Hogan [17] during the investigation realized in the $80^{\prime} \mathrm{s}$ with the population of Cubatão, São Paulo State, Brazil, a city located close to a great petrochemical complex.

So, it is possible to see that behind attitudes and conceptions about a problem, are hidden values that need to be recognized and properly considered in the educative task. Two poles of the question arise: the values exhibited by the individuals and communities to which they belong and the environmental values considered more desirable. How to deal with these poles?

In terms of the historical character of the values and moral, many persons consider that it is not appropriate to establish principles to our society, defending the acceptance to any position. However, this paper agrees with Puig [18] who considers that the proposal of education involving values should not be based on extreme models departuring neither from an absolute conception of values nor from a relativist conception. In the first case, the values would be considered in the educative task from an authoritarian power that would intend to regulate the aspects of the personal and social life. In the second case, regarding the conviction that the values are subjective, it would not be possible to assure that a rule or some behaviour would be better than another. However, according to Puig [18], "steps forward are provided every day for a definition of moral education based on the rational and autonomous construction of principles, values, and rules. This model does not defend absolute values, however, it is not relativist. It affirms that there are possibilities based on the reason, dialogue, and desire of value, which can allow us to determine some valuable principles that, despite to be abstract and formal, may convert in enough guides of the judgement and human behaviour." 
Based on this referential, it is possible to see the need of working with the individuals from conceptions concerning to questions involving environmental risks, trying to analyze the related values (cultural, economic and other, for instance, involving science and technology) and also the appreciation and analysis of other ethically more desirable values.

It is opportune to point out here the possibilities that the aesthetic appreciation may offer to the work with values, not only through the aesthetic experiments involving the appreciation of the natural beauty desired to be valorized, sustained or promoted, but also through the ugliness or dissatisfaction caused by the situation of environmental degradation desired to be solved. In this direction, are important the considerations of Bonnett [19], who claims the attention to the use of "more intuitive, felt, poetic ways of understanding the environment and thus to the potential of art, drama and literature to contribute to the entreprise".

The process of recognizing, analysis, and appreciation of values is reinforced in the proposals of educational work with values, constituting a step that can allow the construction of more appropriate views, and also the involvement and adoption of desirable values.

\subsection{Political participation}

The previous objectives complement and integrate to this third aspect, considered, as already referred to, as a perspective of a much wider action than the simple change of individual behaviour. The new approach to environmental education emphasizes this aspect that is considered more coherent and acceptable from a democratic point of view .

Having in mind the democracy as the directional principle, Calvo and Franqueza [20] attribute that the dialogue, negotiation, and desire of consensus are the necessary instruments for the solution of conflicts, being the participation of the individuals in this process an essential part of their capacitation. So, according to this proposal, the engagement of individuals in real projects is one of the best ways to reach such objectives, through the existence in collective spaces of organization and negotiation, as well through the recognizing and utilization of the social spaces already available.

\section{Final considerations}

Despite to know that the possibilities of consensus and harmonization of interests among different social segments is a task neither easy nor simple, and also that the environmental field emerges principally as a place of disputes among interests and divergent groups, this proposal still remains as the best option of action, if the desire is not to consider authoritarian and non-democratic proposals for the conduction of the problem. It also exhibits a benefit according to Glasbergen [3]: "Disputes may make critical issues more acute, but they may also induce exploration of alternatives and the creation of new institutions beneficial to society. Social conflict is also a vehicle for social progress." 
The clearness in terms of the choice of this option must be conducted to the educative process, and also "to permeate" it, what also is not an easy task. This is a challenge to our traditional visions and practices of teaching and learning, but that is the real way to do an effective environmental education.

Sterling [21] warn us to the risk of pursuing education for environmental management and individual behavioural adjustment as an alternative to more fundamental structural change: the more emphasis that is put on it, the more the intrinsec value of environmental education (the nurturing of the autonomous, empowered and critical individual) may be overlooked, and perhaps even negated. He insists that, whatever educational model is used, it needs itself to reflect wholeness and coherence, so that the microcosm - the specific lesson or activity - suggests and supports the macrocosm of broad educational philosophy and direction.

In the end of his text, Sterling [21] argues: "How do we create truly sustainable, ecologically sound, resilient and healthy systems and societies? If education is for anything, it has to be reorientated for this".

Finally, it is very important to emphasize that this is an intense and deep change that claims for an effective financial support to conveniently prepare all the educators in order to conduct this process. And, of course, it claims for a decisive political wish to make it.

\section{References}

[1] Toynbee, A., A Humanidade e a Mãe-Terra, Rio de Janeiro: Zaar Editora, 1979.

[2] Gonçalves, C.W.P., Os (des)caminhos do meio ambiente, São Paulo: Editora Contexto, 1989.

[3] Glasbergen, P., Environmental dispute resolution as a management issue : towards new forms of decisin making. (Chapter 1) Managing environmental disputes:Network management as an alternative, ed. P. Glasbergen, Kluwer Academic Publishres: Netherlands, pp.1-17, 1995.

[4] Neace, M.B., Sustainable development: a critique and proposal.(Section 1) Ecosystems and Sustainable Development, eds. J.L.Usó, C.A.Brebbia, H.Power, Computational Mechanics Publications: Southampton, pp. 105113, 1998.

[5] Layrargues, P.P.L., Educação para a gestão ambiental: a cidadania no enfrentamento político dos conflitos socioambientais. Sociedade e Meio Ambiente: a Educação Ambiental em debate, eds. C.F.B. Loureiro, P.P. Layrargues, R.S.Castro: Cortez Editora: São Paulo, pp.87-155, 2000.

[6] Corcoran, P.B. \& Sievers, E., Reconceptualizing Environmental Education: Five Possibilities. The Journal of Environmental Education, 25(4), pp.4-8, 1994.

[7] Fien, J., Robottom, i., Gough, A.G. and Spork, H., The Deakin-Griffith Environmental Education Project. (Foreword) Environmental Education: a 
pathway to sustainability, ed. J.Fien, Deakin University: Geelong, pp.vii-xii, 1993.

[8] Fien, J. \& Trainer, T., Education for sustainability. (Chapter 1) Environmental Education: a pathway to sustainability, ed. J. Fien, Deakin University: Geelong. pp.11-42, 1993.

[9] Breiting, S. \& Mogensen, F., Action Competence and Environmental Education. Cambridge Journal of Education, 29(3), pp.349-353, 1999.

[10] Uzzell, D., Education for Environmental Action in the Community: new roles and relationships. Cambridge Journal of Education, 29(3), pp.397-413, 1999.

[11] Kyburz-Graber, R., Environmental Education as Critical Education: how teachers and students handle the challenge. Cambridge Journal of Education, 29(3), pp. 415-432, 1999.

[12] Fien, J., Introduction. Environmental Education: a pathway to sustainability, ed. J.Fien, Deakin University: Geelong, pp.4-10, 1993.

[13] Carvalho, L.M., Educação e Meio Ambiente na Escola Fundamental: perspectivas e possibilidades. Projeto-Revista de Educação, 1(1), pp.3-5, 1999.

[14] Riechard, D.E., Risk literacy: Is It the Missing Link in Environmental Education? The Journal of Environmental Education, 25(1), pp.8-12, 1993.

[15] Mandel, V., Comment développer une conscience écologique? La Recherche, 243(23), pp.664-666, 1992.

[16] Santos, M.E.V.M., Desafios pedagógicos para o século XXI: suas raizes em forças de mudança de natureza científica, tecnológica e social, Publicações Dom Quixote: Lisboa, 1999.

[17] Hogan, D.J., População, pobreza e poluição em Cubatão, São Paulo. (Chapter 4) População, Meio Ambiente e Desenvolvimento, ed. G. Martini, Ed. UNICAMP: Campinas, pp.101-131, 1993.

[18] Puig, M.J., Ética e valores: métodos para um ensino transversal, Casa do Psicólogo: São Paulo, 1998.

[19] Bonett, M., Environmental Education and Beyond. Journal of Philosophy of Education, 31(2), pp. 249-266, 1997.

[20] Calvo, S. \& Franqueza, T., Sobre la nueva educación ambiental o algo así. Cuadernos de Pedagogia, $\mathbf{n}^{\circ} 267$, pp.48-54, 1998.

[21] Sterling, S., Environmental Education and sustainability: A view from holistis ethics (Chapter 4) Environmental Education: a pathway to sustainability, ed. J.Fien, Deakin University: Geelong, pp.69-98, 1993. 